\title{
PASTORAL "BLUSUKAN" AS A MANIFESTATION OF INCARNATION THEOLOGY: IN THE CONTEXT OF PURWOKERTO DIOCESE
}

\author{
Antonius Ary Setyawan*
}

\begin{abstract}
The term incarnation is used to illustrate how God humbled Godself by tranforming Himself into a human being like the believers so they can comprehend the Kingdom of God. As Cristians, we are invited to actualize the Kingdom of God in our everyday life. We are called also to promote the Kingdom of God to all creatures especially those who are poor, hungry, and suffering. "Blusukan" 1 as an activity conducted by a priest to go around and come in to the place that is rarely visited or not most people preferred to come is a way to realize the theology of incarnation. With this way, a priest as a shepherd meet the people and get to know them in their real situation. As Jesus - Son of God - who came among the people to save them in the incarnation, the presence of the priests through "blusukan" pastoral strategy become the spirituality of diocesan priest that was expected to answer the needs of the people so that they also experienced the salvation.
\end{abstract}

Key Words: "Blusukan", Incarnation, Purwokerto Diocese, John Mary Vianney, The Spirituality of Diocesan Priest.

\section{INTRODUCTION}

As a Cristians, each time we pray the Lord's Prayer;"...They Kingdom come, They will be done on earth as it is in heaven", we recognize that the Kingdom of God always becomes the centre of hope for all the faifthful. Yet, it is not easy to identify the Kingdom of God in the

* Antonius Ary Setyawan, Graduate of Master Program in Pastoral Studies from Ateneo de Manila University, Philippines. Lecturer at Yos Sudarso Computer Science College, PURWOKERTO.

1 "Blusukan" is a Javanese term. This term means "go around and come in". It was connoted in a place that is rarely visited or not most people preferred to come. 
conceptual aspect nor in the actual occurrence. It becomes imperative to comprehensive grasp the theological concept and its contents in order to explain appropriately to the believers and how it should be done in the pastoral setting.

Here, I intend to discuss one of theological dogmatic themes on theology of incarnation. However, our focus will not theoretically tackle about the concept of the incarnation, rather, it will highlight on how we should practice it corectly in pastoral ministry.

Commonly, the term is used to illustrate how God humbled Godself by tranforming Himself into a human being like the believers, so they can comprehend the Kingdom of God. All Christians people are invited to actualize the Kingdom of God in our everyday life; in the same manner that a Church is empowered by the Holy Spirit, we are called to promote the Kingdom of God. It is thus our duty to ascertain that all human beings would experience the real existence of the Kingdom of God through the relevant pastoral approaches.

\section{THE BRIEF PROFILE OF PURWOKERTO DIOCESE}

Presently, there are 37 dioceses situated in Indonesia. Purwokerto, as one of the dioceses located in Central Java covers an area of 13.870 square kilometers. It consists of 12 districts and two municipalities occupied by the Muslim-majority. Geographically and economically, the Purwokerto Diocese includes the majority of rural areas. Yet, two areas - Tegal and Pekalongan city - situated in the northern coast of Java, exhibit modern living and cultures. The two cities are on the economic pathway of Jakarta, emulated by East Java and other cities in the eastern part of the two cities.

However, these two cities are smaller and 'less developed' in terms of the urban culture and development when compared with the surrounding cities such as Jakarta, Bogor, Bandung, and Semarang located in the same province of Central Java. Moreover, Purwokerto itself is only a subdistrict of Banyumas district - one of the 35 districts in Central Java province, Indonesia. That is why Purwokerto is considered as a rural diocese. As such, the Bishop of Purwokerto often says that he is a Bishop of a rural diocese ("keuskupan kecamatan").

In general, the majority of inhabitants earn their living from farming. Only a few numbers work as traders, civil government employees, educators and entrepreneurs. Correspondingly, the traditional value, simple way of thinking, rural traditions and cultures are strongly observed among the society. For example, the rural traditions that are still practiced are the value of harmony, cooperation, 
collaboration, and tolerance. These are found in the way people live out "gotong-royong" or mutual cooperation, mutual conference, and the action of helping one another when one of the community members experience calamity or hardship.

In line with this condition, the diocese of Purwokerto with its 23 rural parishes and two metropolis parishes, has been trying to embody the total comprehension as the church is called to be with her people and address their needs through the priority of her apostolic ministry. And one of the significant apostolic ministries that is being prioritized is to make the church a part of the society. In other words, the diocese emphazises that Church is not a separate institution from the society but a part of the society.

Reflecting on the above condition, the diocese highlights the focus of pastoral services on the area of farming and poverty since the two areas are tightly related to the situation of the members of the community within the diocese. Further, the diocese underlines the five years agenda of diocesan pastoral strategies planning on the establishment of "paguyuban" or empowering community. ${ }^{2}$

Based on the mentioned themes of the primary focus of the diocesan pastoral agenda, the Church of Purwokerto would like to become a part of the local community by working hand in hand with its members in facing the issues and concerns surrounding them. Moreover, the Church of Purwokerto opts to apply the mandates of the pastoral constitution regarding the Church in the modern world as stated in Gaudium et Spes article one:

"The joys and the hopes, the griefs and the anxieties of the men of this age, especially those who are poor or in any way afflicted, these are the joys and hopes, the griefs and anxieties of the followers of Christ." (GS. 1)

Since the year of 2000, the diocese has been striving to maintain the presence of the Church in the society particularly in the midst of hinterland communities and the unfortunate groups by actualizing the pastoral model of rural approach. Correspondingly, the Church motivates and encourages its priests and pastoral team to enter into concrete situation of rural life in order to undertand deeply the actual

2 "ARAH HALUAN KEUSKUPAN PURWOKERTO - "Menjadi Paguyuban Pemberdayaan sebagai Tanda Hadirnya Kerajaan Allah", Rangkuman Hasil Musyawarah Pastoral Keuskupan Purwokerto, (Purwokerto, 2012), p. 28. 
needs and circumstance of the members. Asides from that, priests and pastoral workers should not act as the master who just stay silently and wait for the rendering of reports from their community members, rather, the priests and pastoral workers should visit the community, greet them, listen to their concerns, strengthen their faith, and more importantly closely work with them to determine strategies for the improvement of the community.

This kind of pastoral conduct is the new orientation of the diocese since almost 100 years of existence, and it's pioneer mission has been to establish parishes, parochial centres, and religious convents in the centres of the city. Subsequently, the life style and circumstance of the hierarchy in the city is directly inserted in the rural mission in which life is totally different from the life situation and condition of the metropolis. As a result of this new orientation, the Church is immersed rather than separated from the actual problems that the community members experience. To sum up, the new pastoral strategies designed by the Church endeavors to respond to the actual needs of her community.

\section{JOHN MARY VIANNEY AND THE SPIRITUALITY OF DIOCESAN'S PRIEST}

Discussing about pastoral approach in the rural context would always remind us about one famous saint, Saint John Mary Vianney. Historically, Jean Baptist Marie Vianney, who is also known as "the Priest of the Ars", was born in Dardilly, nearby Lyon, in the south of France, on May 8, 1786. ${ }^{3}$ Vianney was born as the forth child of simple family of Mathieu Vianney and Marie Beluse. The family resided in a rural area and had few small lots located at the same compound with their residence. Jean was inspired by the care and concern of his parents towards the poor despite their own simple life. Their parents would always welcome the neighbors who seeked for help in terms of foods and other necessities. Like his parents, Jean sincerely served those needy people who came to their house seeking for help. Moreover, he would go to the streets and take home their torn clothes and give to his mother to be repaired. When he turned into a teenager, Jean loved to help his parents work in the farm and animal husbandry.

His personal experience and the good teachings of his parents inspired Jean to be a priest. Yet, the French revolution did not permit him to pursue his desire until he reached the age of 17 because many

${ }^{3}$ Catholic Encyclopedia, available [on-line]:

http://www.newadvent.org/cathen/08326c.htm (Accessed on 20/09/2016). 
churches were closed and priests were evicted from parishes and monasteries. Besides, his father do not have enough fund to finance his education. It was only when he turned 19 did his desire to be a priest was granted through the assistance of his parish priest. Nonetheless, Jean encountered difficulties in pursuing his studies due to his low intellectual capacity. Yet, his spirituality and holiness of life that he observed during the formation and studies in the seminary allowed him to be ordained a priest at the age of 29 .

Vianney was known as a simple and humble priest. He soon, became the example of holiness and model of inspiration among his parishioners. He never abandoned his prayer life despite the hectic schedules of being a parish priest. Further, he strongly observed penance and fasting at the same time giving his share to the poor.

Correspondingly, Vianney experienced a new stage of his priestly journey when he was assigned to a rural parish in the town of Ars. Ars was a small parish and far from the festivity. Here he discovered that his parishioners had lost the meaning of their faith and spiritual life. He thus exerted extra effort to enkindle -the faith that was almost extinguished in Ars. He accordingly did the door to door pastoral visit to get familiar with his parishioners. His compassion for conducting pastoral visit bore result. His parishioners began to acknowledge his presence and personality. They started to come for consulation and share their personal concerns to him. In turn, Vianney never gets tired and bored to welcome gratefully his parishioners. He would always make himself available for others in need. This change, provided opportunities for Vianney to share about spiritual experiences and God's grace to his parishioners. Moreover, he did all these pastoral services with love and compassion and he never forced them to follow everything that he had taught them. In addition, he practiced compassion, humility, and never passed any unkind judgment on them although he knew the mistakes or wrongs they committed. His actions mirrored the sincerity of heart of a shepherd who gives comfort and peace to his flock.

We learn from Vianney's humility in acknowledging his own intellectual limitation yet was open to the grace of God which moulded him as an instrument to spread His love through examples of positive attitude and simple actions. The sincerity in doing pastoral visits, the readiness for pastoral consultation, his prayer life, and abstinence became concrete pastoral concern from the shepherd to his flock. 
From the personality of Vianney we can seen "healing personality" wherein, he cured a number of people who came to him seeking for help. Moreover, Vianney was moved by the Holy Spirit in most of his acts and deeds. He brought into prayers and abstinence all the concerns and struggles that he encountered. This act indicates that, Vianney surrendered everything to God and recognized that he was only an instrument to bring into reality the will of God within him.

Aside from that, we can learn from Vianney the appropriate ways to perform the actual works (a searcher for the concretely best service). It can be seen through his endless efforts in finding various ways to execute pastoral works in order to awaken the faith of the believers. Although, he oftentimes failed to derive people to come closer to God and engaged in pastoral activities, this made him retool the pastoral strategy that he executed. He humbly asked cooperation from his parishioners to determine the rightful and effective methods for better service.

As a shepherd, we should become a credible person. This aspect thus, is also found in the person of Vianney. Thousands of people came to him for consultation and confession. It is clearly observed that Vianney is regarded as a credible person who always observes spiritual practices and virtues as well as strive for his holiness.

Jean Maria Vianey was not a contemplative priest who would constantly sit in the midst of prayer and contemplation. He spent most of his time working and giving service to his parishioners and people around him. However, he was fully aware that he was not a social worker that did acts without motivation of faith. Yet, he believed that pastoral service was actually a form of prayer which he should live out.

It thus becomes the main reason for the diocesan priests to imitate what Vianney has modeled. He performed the will of God through actual actions and services but he also collaborate with God to strengthen and guide him in every deed that he performed. In addition, he practiced prayers and abstinence to discover more the will of God in him and begged for God's grace to actualize the mission into reality. The Latin term is famous among the diocesan priests "contemplativus in actione" corresponds to Vianney's life of service. 
Antonius Ary Setyawan, Pastoral "Blusukan" As a Manifestastion ....

\section{SPIRITUALITY OF THE GRASSROOTS AND “BEING EARTH, WATER, AND AIR"}

Learning from the life experience and example of St. John Marie Vianney, there is one important point that should be underlined. As a priest, he did not create a distance between him and his parishioners. He conscientiously visited them, acknow-ledged their needs, accompanied them through words of encouragement, gaves spiritual advice, and most importantly prayed for them and did abstinence for the conversion and prosperity of his parishioners.

In their capacity, priests called to theologize contextually in line with the circumstance of the people we serve as Vianney did. Indeed, theology is always related to the practical application in everyday life since human affair is inseparable from faith. If theology only focused on the biblical writings and never touches the actual situation of people, theology then just acts as an ineffective discourse. Thus, theology should motivate and empower people to do something good for others to create peace, justice, and prosperity for the common good.

In this light, we do agree with the expression of Mgr. Julianus Sunarka SJ (the retired Bishop of Purwokerto), who always uses his reflection in his homilies or words of encouragment that in becoming a priest, we should "mem-bumi, meng-air, dan meng-udara" (be an - earth, water, and air) for those in need. Bishop Sunarka highlights and encourages the priests to comprehend fully the spirituality of the grassroots.

Theology of grassroots is actually the reflection of experience in giving service and striving with people (parishioners) who are grounded and inspired by the Words of God. This theology intends to give support to the priests and pastoral workers in the struggle for peace and justice amidst the pluralism of religions and cultures. ${ }^{4}$

Subsequently, the theology of grassroots is the contemplation about the grasses which regarded as the plants that seem priceless compared to other plants. Yet, when the storm comes, the grasses would stand still unlike the other plants that would likely topple. In addition, the grasses possess the willingness to provide itself for the needs of others. For instance, it is willing to be consumed by animals to preserve their life. Further, the grasses also become a symbol that never fade in all the season even though it encounters problems, oppression, and mistreatment. These detrimental acts never make the grass fades or dies.

4 Cf. Asnath N, Natar (ed), Teologi Operatif, (Jakarta: BPK Gunung Mulia, 2003), p. 177. 
In the book of Songs, the grass is described as the source of life. It means, the grass does not live for itself but to complete the need of others (cf. Psalm 65:13). Likewise in the book of Isaiah, the grass is identified as the plant that withers an inevitable process of life similar in all other creatures. Nevertheless, the decay it experiences does not mean the end of it, because the grass would grow and rise again when its season comes (Isaiah 40: 6 -8).

Mirroring on the reflection above, the thelogical explanation of the grass should be the spirituality of priests and pastoral workers who hold firmly onto the hope to keep alive even when we face various demands and difficulties beyond one's capacity to handle. Yet the symbol of the grass continue to inspire us.

Josef Widyatmadja in his book entitled "Teologi Operatif" 5 also identifies the characteristics of the grassroots theology as it

"would always focus on the minorities with all concerns that they suffer of. Besides, this theology gives priority to the local culture/tradition, experiences, and deep comprehension of the people whom we serve in the spirit of unity with one another. This theology is not universal, but remind local to underline its main concern on the actual and current problems rather that the past or the present."

In line with the concept of Josef Widyatmadja on grassroots theology, Bishop Julianus Sunarka, SJ again emphazises the self-image of diocesan priests in the question, "Who is actually a diocesan priest?" According to Bishop Sunarka, a diocesan priest is a priest who is being called from the midst of the community to strive and battle with and for the community where he belongs ${ }^{6}$ or in Javanese dialect of Banyumas, Purwokerto oftentimes said: "Romo Projo iku laire sekang umat, gedhene tuli sekang umat, lan gole berjuang bareng umat." It is intepreted as "the diocesan priest is born from community, grow up in community, and thus, strive with community."

Based on the previous explanation, it is clearly understood that a diocesan priest is officially dedicated for the growth and life of the local Church which, we understand as the diocese. In addition, diocesan priests together with the bishop and other priests play an important role in determining the pastoral strategy for the diocese including other

${ }^{5}$ Ibid. 179.

${ }^{6}$ Mgr. J. Sunarka SJ, Imam Diosesan, Siapakah Dia?, (Yogyakarta: 1987), p. $2-3$. 
necessary matters and concerns. In short, the diocesan priests act as the episcopal extension of the bishop in handling the pastoral works and accompaniment among the community members/parishioners within the parochial areas.

Given the above portrait of the diocesan priest, a person who intends to be a diocesan priest must possess a strong Christian faith and manifest a willingness to bring Jesus Christ and His Kingdom to the people where he belongs. Moreover, he must love the Church wholeheartedly with his capacity and potentiality. Further, he should possess the distinctness of a cultural observer who clearly understands and appreciates the uniqueness of each culture and its values to have the capacity for thoughtful and purposive actions as part of his pastoral approaches.

In terms of personality, a diocesan priest is expected to be wise, open for options, understanding the need of others, appreciative of the presence of others, and could leave his own need for the sake of others. Besides, the important thing that we should always remember is that, a diocesan priest is a religious person guided by the Holy Spirit to provide spiritual life. As part of his commitment, he is expected to be a genuinely prayerful person who is sensitive towards the needs and life of the society and community. It thus, becomes the figure or image of a diocesan priest to uphold his priesthood vocation.

\section{THE STRATEGY OF PASTORAL "BLUSUKAN" AS A MANIFESTATION OF INCARNATION THEOLOGY}

Upon understanding the self-image and characterictic demands of a diocesan priest, the priest should also be equipped with a good strategy to pass on the spirituality that he has observed and practiced. The relationship between a priest and his people/parishioners can be established if there is a proper channel of communication where humility and emphaty take the initiative in establishing the bridge between him and his people/parishioners.

Reflecting on the acts of St. John Marie Vianney in which he loved to visit his people (parishioners), the diocese of Purwokerto then formulated a pastoral strategy knows as "pastoral blusukan." The word "blusukan" was derived from the word "blusuk" which means "come in". When someone says "diblusukake ke lumpur", it means the person is immersed into the mud. The term "blusuk, diblusukake, and blusukan" have no registry in Indonesian dictionaries because it is derivation of a Javanese language. It is used by the locals in rural areas or far hinterlands. 
In the Javanese context, "blusukan" refers to people who like to rove into restricted areas that encounter predicaments but has never been solved. Spiritually, the intention is to discover the condition and situation of the local nature and inhabitants in the covered area. Subsequently, they would reflect critically to identify the will of the Supreme Power. The same connotation is referred to "blusukan" which means "try to know it." Nevertheless, the term "knowing" here does not simply mean knowing the surface, knowing more intimately, to the extent that such a deep knowledge strongly motivates the knower to serve with the whole heart and soul.

Relate to Purwokerto diocese which is a rural diocese, the "blusukan" becomes the primary and effective strategy to form "pastoral pedesaan" (rural pastoral strategy). The strategy of "pastoral blusukan" signifies the actual act of a priest tending his flock by going from one village to other village to become more familiar with the nature and the native culture in order to evangelize, encourage a process of growth in sanctity, pastoral service and develop local association known as "paguyuban".

By applying the "blusukan" strategy, the priest as the shepherd internalizes and becomes so familiar with the life patterns and features of rural residents' lifestyle living like how they eat, dress up, and conduct rest so that he discovers new sources of life in their midst. Similarly the priest strives to know how these people conduct their work in the farm, observe their hygienic standard, manage their household, and the way they do farming, livestock, and come to understand how they manage time, money, and educate their children. Furthermore, "blusukan" would permit the priest to understand the way children apply the lessons and values they get from parents and the school. The principle establishes relationship and assists parents or give contribution to the environment. For example, it provides the priest with knowledge on how families spend time together in meals, chats, recreation, or prayers and how they discuss faith, love, and hope.

If "blusukan" is intended to be one of pastoral strategies, it should be taken into serious account otherwise there is a tendency to make it as a hobby or personal interest. Therefore, the priest should view this strategy as a medium to deliver the theology of incarnation. Generally known, theology of incarnation teaches and believes that Jesus Christ as the second form of Trinity whom is also disclosed as the Son of God, present and enter into the world to give Himself totally for the salvation of human kind. (Mat 20:28) 
Antonius Ary Setyawan, Pastoral "Blusukan" As a Manifestastion ....

To comprehensively acquire the meaning of incarnation, the word of "incarnation" is derived from the ecclesiastical Latin verb incarno which, the verb incarno itself comes from the prefix in-and caro, "flesh", meaning "to make into flesh" or "to be made flesh". The verb incarno is drawn from the Gospel of John "et Verbum caro factum est" "and the Word was made flesh" (John 1:14). ${ }^{7}$

From the wider understanding of the concept of theology of incarnation, it becomes clear that "blusukan" is an apt pastoral strategy that vividly and concretize the incarnation, experience by God-madeflesh in the person of Jesus. In this manner, the presence of a priest in the "blusukan" pastoral approach should not ostentatiously exhibit his outward apprearance as a priest. Rather he should wear the common attire and use things that the local community possesses. It would then make him a part of the community and he will be easily welcomed by the people around him. In addition, the presence of priest in the "blusukan" pastoral approach should transform his presence to become a 'presence of grace' for others (his parishioners). In other words, the presence and action of the priest should not be a burden to the community. If the community has to attend to his specific needs, then the priest fails to employ "blusukan" strategy.

\section{CONCLUSION}

Incarnation theology is the pastoral-theological basis for a pastoral strategy of blusukan. In the context of the Purwokerto diocese, incarnation theology is lived concretely and realized through the decision to choose "blusukan" pastoral strategy as a way to bring God and His Church among the people. Through the presence and closeness of relations between the people and the Church - represented by the priests -, the people could experience the Kingdom of God present in the reality of their lives. The Kingdom of God is an illustration of the current situation in which God becomes a king. When God's reign, all people will experience justice and prosperity. No more suffering and injustice that happened in Purwokerto.

But in the reality, social problems such as poverty, injustice, corruption, and the problems related to human rights abuses and less respect for human dignity still prevalent. Those problems are against with the situation of peace, justice, and welfare as described in the

7 McKim, Donald K., Westminster dictionary of theological terms, (Louisville, KY: Westminster John Knox Press, 1996) p. 140. 
situation from the Kingdom of God. In this situation, we underline the vision the diocese Purwokerto who want to realize the God's Kingdom. Hence, the Church and all of us as followers of Jesus invited to realize that in the concrete as that we need to make faith and has a good theology

The concrete of theology it is not enough to discuss or supplication. Theology means present, touching, greet, to feel and compassion with anything for people. For that we need to present in the community and involved in, like grief and the people, and from these things we have been confirms, hope and love people. In concrete terms, writers have proposed several things concrete can be done in achieving theology incarnation strategies pastoral "blusukan". First, do what is usually done by priests and made a congregation at society not only when mass but make a schedule specifically for a nation that other people visited will invited, the priest also get to know closer one with another or family one another.

The second step conference after interaction and presence of priests in the nation is reflection. Reflection means justice, think wisely, analyzed and find insight through the nation. From these things, we invited to find root problems and value who will be built the and situation found. After discovering the root problems, we invited to determine a strategic program to answer the root of the problem from problem that happens. The next step is to involve the choice action to achieving to respond problems that exist. Steps is performed in concrete terms in prayer. Through our prayer, we just fate what has been efforts and intentions whether the situation to the lord. Hopefully against her will happen for us and not our will (man) happened. But said this was also highlight drew depart from the company and teachings church.

The final step is implementing the program or choice the act of faith vividly. Has good faith through the action of this can be implemented in cooperation with anyone who want good. Thus finally, the church as the body mystical of Christ call themselves as well as the head of the church of Christ alone in the world of men with all the real situation. Incarnation as a basis for pastoral and manifested through pastoral's strategy "blusukan" are expected to bring grace and salvation to the other's. 
Antonius Ary Setyawan, Pastoral "Blusukan" As a Manifestastion ....

\section{DAFTAR PUSTAKA}

“ARAH HALUAN KEUSKUPAN PURWOKERTO - "Menjadi Paguyuban Pemberdayaan sebagai Tanda Hadirnya Kerajaan Allah", Rangkuman Hasil Musyawarah Pastoral Keuskupan Purwokerto, (Purwokerto, 2012)

Asnath N, Natar (ed), Teologi Operatif, (Jakarta: BPK Gunung Mulia, 2003)

Catholic Encyclopedia, available [on-line]: http://www.newadvent.org/cathen/08326c.htm (Accessed on 20/09/2016)

Donald K., McKim, Westminster dictionary of theological terms, (Louisville, KY: Westminster John Knox Press, 1996)

Groenen ofm, C, Sejarah Dogma Kristologi, Perkembangan Pemikiran tentang Yesus Kristus pada Umat Kristen, (Yogyakarta, Kanisius: 1987)

Hardawiryana, SJ, R (Penertemah), Dokumentasi dan Penerangan KWI, DOKUMEN KONSILI VATIKAN II, (Jakarta, Obor: 1993)

Sartono Kartidirdjo, A., Sejarah Keuskupan Purwokerto 1927 - 1992, (Yogyakarta, Pusat Studi dan Dokumentasi Sejarah Indonesia Fakultas Sastra Universitas Sanata Dharma: 2002)

Sunarka SJ, J. Imam Diosesan, Siapakah Dia?, (Yogyakarta, Kanisius: 1987) 
“KATEKISMUA GEREJA KATOLIK” - (Ende, Arnoldus: 1995)

Konferensi Wali Gereja Indonesia, "IMAN KATOLIK" - "Buku Informasi dan Referensi", (Yogyakarta, Kanisius: 1997)

Boydo Rajiv Evan Duvano Hutagalung, IMPLIKASI PEMIKIRAN KRISTOLOGI LOGOS DALAM BINGKAI PERSPEKTIF TEOLOGI PROSES TERHADAP RELASI ANTAR AGAMA, Indonesian Journal of Theology 3/2 (December 2015): 225-248

McDowell, Josh\& Bart Larson, “Adakah Yang Mustahil bagi Allah? Allah Menjadi Manusia", (Bandung: Lembaga Literatur Baptis, 2000). 